\title{
エクトロメリア・ウイルスの免疫血清学的研究
}

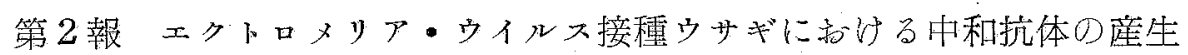

並びにその性状について。

\author{
藤崎優次郎 - 堀 江 喜 一*
}

\section{IMMUNOLOGICAL AND SEROLOGICAL STUDIES ON THE ECTROMELIA VIRUS}

\section{SECOND REPORT: DEVELOPMENT OF NEUTRALIZING ANTIBODY IN RABBITS INOCULATED WITH THE ECTROMELIA VIRUS AND ITS CHARACTERISTICS}

YUUJIRO FUJISAKI and KIICHI HORIE

$$
\text { [受稿 } 4 \text { 月 } 20 \text { 日，1961] }
$$

第1報において，私共はエクトロメリア・ウイルス (以下 E-ウと略) を接種したウサギの血清中には，E-ウ 飞対する各種抗体の産生が諗め難いことを述べた。专

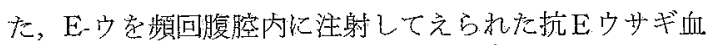
清には，E-ウに対する中和能が認め難いのに反して，ワ クシニア・ウイルス (以下Vーウと略)に詨してはかなり 高い中和能が認められることも報告した。

今回埂に，多数のウサギを用いて E-ウによる免疫 を抗こない，方法論の上からむ检討を試みつつ，E一方接 種ウサギにお忟和抗体産生の問題, 並びに抗Eウサ ギ血清の中和反応上にお行る 1,2 の性状についてV・ウ と対比しながら検討したのでその成績を報告する。ま た，本研究中に遭遇した $2 ， 3$ の䦗題点，すなわら E-ウ 先疫ウサギのV.ウに対する感染防御能，まるいは免疫 方法がそこに産生される中和抗体の性状に执よ洔寸影響 などについても若検討したので，あわせてここに報告 专る。

実験に用いた材料および実験方法は第 1 報にお打ると ほぼ同様であるが，それらの詳細については実験成績の 項でその都度述心゙る.

\footnotetext{
* 国立予防衛生研究所

Department of General Biologics Control, National Institute of Health, Tokyo
}

\section{実 験 成 績}

実験 I 抗 $\mathrm{E}$ ウザ血清の中和能について

実験 $\mathrm{I}-1$ 新たに E-ウでウサギを強度に先疫し，そ れらの血清の E-ウ执よびV-西两ウイルスに対する中和 能子同時に測定した。 免疫方法は，E-少感染マウス肝 10\%乳剂(マウス腹腔内 $0.2 \mathrm{ml}$ 接種で $\mathrm{LD}_{50}: 10^{-7} .^{0}$ ) 5 $\mathrm{m} 1$ 学 1 週閆隔で 5 回腹腔内に注射し，最終注射後 2 週 目に採血した(これを E免疫群と仮称する)，使用ウサギ

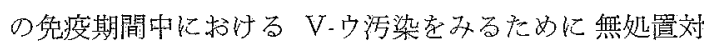
照群並びにN免疫群（正常マウス肝乳剂を用いてE免疫 群と同様な方法で少ギを免疫したもの）をおいた。

成績は表 1 に示すよ 5 に，E免疫群の中にはNo. 2 の ごとく E-ウに対寸る中和能 $(\log N I ： 0.1$. 0.3) ダ全く 認められないものもあつたが，No. 4 のごとく E-ウに 対する中和能 $(\log N I ： 2.8)$ 汃認女られるウサギもあつ た.しかしながら，誤差範囲内とも考えられるよらな中 和能の值を示すウサギが多いように思われた。 またこ れらのウサギの血清は，Vーウに対して概ねかなり高い中 和能を示したが，No. 4 のごとくV-ウに対する中和能 は他のものより却つて低いものもあり，E-ウに対扵る中 和能とV-ウに対する中和能との間には平行関係注みら

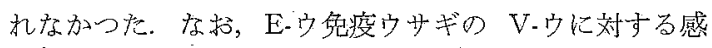
染防御能を歹るため, 兔疫終了後の各ウサギの背部皮内 
Table 1. Neutralizing capacity of anti-ectromelial rabbit serum against ectromelia and vaccinia viruses (No. 1)

\begin{tabular}{c|c|cc|c|c}
\hline \multicolumn{2}{c|}{ Virus } & \multicolumn{2}{|c|}{ Ectromelia } & Vaccinia & Result of protection test*** \\
\hline \multirow{3}{*}{ E groum } & No. 1 & 1.1 & 1.6 & 4.0 & $10^{-4}$ \\
& No. 2 & 0.1 & 0.3 & 4.0 & $10^{-4}$ \\
& No. 3 & 1.9 & 2.1 & 5.0 & $10^{-4}$ \\
& No. 4 & 2.8 & & 2.0 & $10^{-4}$ \\
& No. 5 & 1.8 & & & $10^{-3}$ \\
\hline \multirow{2}{*}{ N group** } & No. 6 & 0.3 & & 1.0 & $10^{-4}$ \\
& No. 7 & & & 1.0 & $10^{-4}$ \\
\hline \multirow{2}{*}{ Normal } & No. 8 & & & $10^{-4}$ \\
& No. 9 & & & & $10^{-4}$ \\
\hline
\end{tabular}

Notes * : Injected with $5 \mathrm{ml}$ of $10 \%$ emulsion of the ectromelia mouse liver $\left(\operatorname{LD}_{50}: 10^{-7}\right)$ five times intraperitoneally at weekly intervals, and bled 2 weeks after the last injection.

** : Instead of the ectromelia mouse liver, the normal mouse liver emulsions were injected in the manner as in E group.

*** : Result of titration test with vaccinia virus, that is, each rabbit was inoculated with 0.1 $\mathrm{ml}$ of each of the gradually diluted virus suspensions intracutaneously immediately after the bleeding for the determination of neutralizing capacity.

Expression of the neutralizing capacity: Log. difference in titer between control and undiluted test serum

Table 2. Neutralizing capacity of anti-ectromelial rabbit serum against ectromelia and vaccinia viruses (No. 2)

\begin{tabular}{|c|c|c|c|c|}
\hline Serum & Virus & Ectromelia & Vaccinia & Result of protection test* \\
\hline \multirow{3}{*}{$\begin{array}{c}\text { E group** } \\
\text { (I) }\end{array}$} & A & 2.3 & 3.5 & $10^{-3}$ \\
\hline & B & 1.8 & 1.5 & $10^{-3}$ \\
\hline & C & 1.7 & 3.5 & $10^{-4}$ \\
\hline \multirow{3}{*}{$\begin{array}{l}\text { E group*** } \\
\text { (II) }\end{array}$} & $\mathrm{D}$ & 0.7 & 0 & $10^{-3}$ \\
\hline & $\mathrm{E}$ & & 0 & $10^{-4}$ \\
\hline & $\mathrm{F}$ & 0.5 & 2.0 & $10^{-4}$ \\
\hline \multirow{3}{*}{$\mathrm{N}$ group $* * * *$} & G & -0.6 & 0 & $10^{-4}$ \\
\hline & $\mathrm{H}$ & & 0 & $10^{-3}$ \\
\hline & I & & & $10^{-4}$ \\
\hline
\end{tabular}

Notes *: See notes in Table 1.

**: Injected with $1 \mathrm{ml}$ of $10 \%$ emulsion of the ectromelia mouse liver five times intraperitoneally at weekly intervals, and bled 10 days after the last injection.

*** : Injected with $5 \mathrm{ml}$ of $10 \%$ emulsion of the ectromelia mouse liver, and bled 10 days later.

***** : See notes in Table 1.

に，10 倍階段稀釈された V-ウを接種してその発痘力価 をしらべたところ，表に文られるごとく対照群との間に

差はみられなかつた。

実験 I -2 前記の成績を検討するため，免疫量を変 えて略々同様な穾験を繰り返えしまこなつたところ，表 2 に示すよらな成績が得られた。即ちE-ウ $10 \%$ 乳剂を
$1 \mathrm{ml}$ ずつ 5 回腹腔内に 注射した E 免疫群 (I) におい ては，3頭の中 1 頭 $(\mathrm{A})$ は E-ウに対する中和能が認め られたが，2頭（B，C) は僅かながら中和能を有してい るのではないかと思われる程度であった、V、ウに対する 中和能は，3頭の中 2 頭に認为られたが，前実験に扮け ると同様に両中和能の間には平行関係注みられなかつ 
tic.

また，E-ウ $10 \%$ 乳剂 $5 \mathrm{ml}$ を 1 回腹腔内に注射したE 免疫群(II)に抒いては，Fウサギ血清が V-ウに対して 僅かな中和能（log NI：2.0）起示しほかは，E-ウ， Vーウ雨ウイルスに対する中和能は，共に認められなか つた.

以上のよらな実験成績から，E・爰でウサギを強度に免 疫した場合にも，E一汶対する中和能が明らかに認めら れる血清が得難いこと柱事実である驾，ウサギにおいて む，あるいは E-ウに対する中和抗体学産生しているの かもしれないと考えられた。

なお，免疫期閶中同一場所に飼育したN免疫群拉よび 無処置対照群ウサギの血清が示した E-ウおよびVーウに 対する中和能の值加ら，実験 1,2 を通じて免疫期間中 Vーウの励染はなかつたで女ろうと考えられる。

さて，今回の実験に拉いては，E-ウ免疫ウサギがけず れもV、ウに対する発痘阻止能を示さないという成績が えられているが，この点については若子検討を就なつ たので，その結果注別項で述心゙る.

実験 II 抗Eウサギ血清とE-ウおよびVーウとの中和 曲線につけて

次に，E一ウに対して，岁るいは誤差範囲内ではないか とも考えられる低い中和能を示吉抗Eウサ任清中に果 してE-ウに対する中和抗体方存在しているの加否加,

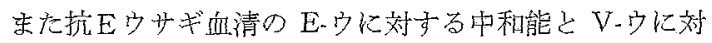
する中和能とが平行しない点定解明するため，血清稀僠

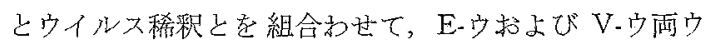
イルスを用いた Box 中和試験をおこない，それぞれの 和る中和曲線を求めた。

\section{枋料と方法}

\section{E-ウに対する中和曲線の求め方}

抗血清を先ず原液から 100 倍あるい性 1000 倍まで 10 倍階段稀瀵し，各稀䐆血清とあらかじめ10 倍階段稀釈 した E-ウ液しを等量混合して， $37^{\circ} \mathrm{C} 2$ 時閒反応させた 後, 1 稀釈段階につき 10 匹のマ爫スの絪内に接種した. 14 日閒の観察の後, 血清の各濃度における $\mathrm{LD}_{50}$ をプロ ビット法によつて算出した。血清の代りにメジウムを使 用した対照列の $\mathrm{LD}_{50}$ 孛同時に求め, 対照列の $\mathrm{LD}_{50}$ に 対する血清列の $\mathrm{LD}_{50}$ の比の対数をとり，それを中和能 (log NI) とした。横軸学 血清濃度, 縦軸を中和能とし て，血清の各濃度に対する中和能の值をプロットし，各 点を通る回率直線を求わ，それを中和曲線とした。な お，ウイルス量を一定とした血清稀䣋法を用い，各使用 ウイルス锂に対するいわゆる血清の $\mathrm{ED}_{50}$ 算出し，両
者の関係から中和曹線を求めてみた名，上記方法に拠つ た場合と同様な結果がえられている。

2.V-沙に対する中和曲線の求め方

抗血清を先ず原液から 100 倍あるいは 1000 倍まで 10

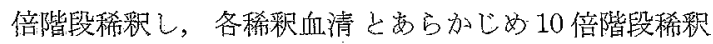

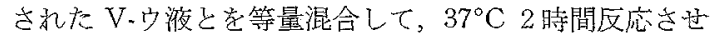
た後, 各混合液を 3 頭のウサギの背部皮内に $0.1 \mathrm{ml}$ つ合計 3 個所接種した. 3 日加ら 7 日の間毎日接種個所 の硬結および発赤の程度を観察し，現われる反応の最高 点にお、て成績の読多とりを扢こなつた。なお，触知で きる硬結をともなつた径 $8 \mathrm{~mm}$ 以上の丘疹の発生した ものを発痘陽性とし，血清の各濃度における $\mathrm{ID}_{50}$ を Reed \& Muench の方法によつて算出した. 血清の代り にメジウムを使用した対照列の $\mathrm{ID}_{50}$ を同時に求め，対 照列の $\mathrm{ID}_{50}$ に対する血清列の $\mathrm{ID}_{50}$ の比の詨数をとり, それを中和能としたＥ宁の場合をほぼ同様にしてその 中和曲線を求めた。

図1はその成績を示したもので每る、図にみられるよ らにV-ウに対する中和曲線は，傾斜が極めて急である のに対して，E一ウに対する中和曲線は概してその傾斜が ゆるやかで，雨曲線は平行しないものと思わ机る。ま た，E一ウに対する中和曲線とV.ウと対寸る中和曲線と の間には，中和能からみを位置の上で一定の相対的関係 がタられなかつた。このことは実験 I において抗 Eウサ ギ血清の E-ウに対する中和能とV-ウに対する中和能し の間に平行関係がみられなかつたことと符合するもので ある、更に，兩ウイルスに対する二つの中和曲線の傾斜 が黑ることから，二つの中和反态恃異つた機作によつて おこなわれている可能性が考えられるので，抗Eウサギ 血清につふてE-ウに対する中和能とVーウに対する中和 能の高低を比心ることは論理上不合理であることがわか つた.

また，血清原液で䛱差範囲内と考光られる程度の低い 中和能を示した血清でも，稀勫血清で測つた中和能を結 ぶ線は，原液でもつを高く明らかな中和能を示安血清の 場合と，一般にその傾斜は同しとみられることから，中 和能怟低が抗体は産生しているとみる心゙きではなかる らか。 なお，実験 I で述心゙た No. 2(log NI：0.1，0.3) のウサギ近清を用いて Box 中和試験をおこなつたとこ ろ，図に外られるように一定の中和曲線がえられなかつ た.このことは No. 2 ウサギ血清中に郝ける中和抗体 の存在は考光難いことを示すものであるう.

実験 III 抗Vウ将血清と E-ウおよび V-ウとの中 和典線

実験【に拉いて述べたように，抗Eウサギ血清対 E-ウ およびV-ウの二つの中和曲線が平行しないことから， 
Fig. 1 Neutralization line of anti-ectromelial rabbit serum against ectromelia and vaccinia viruses
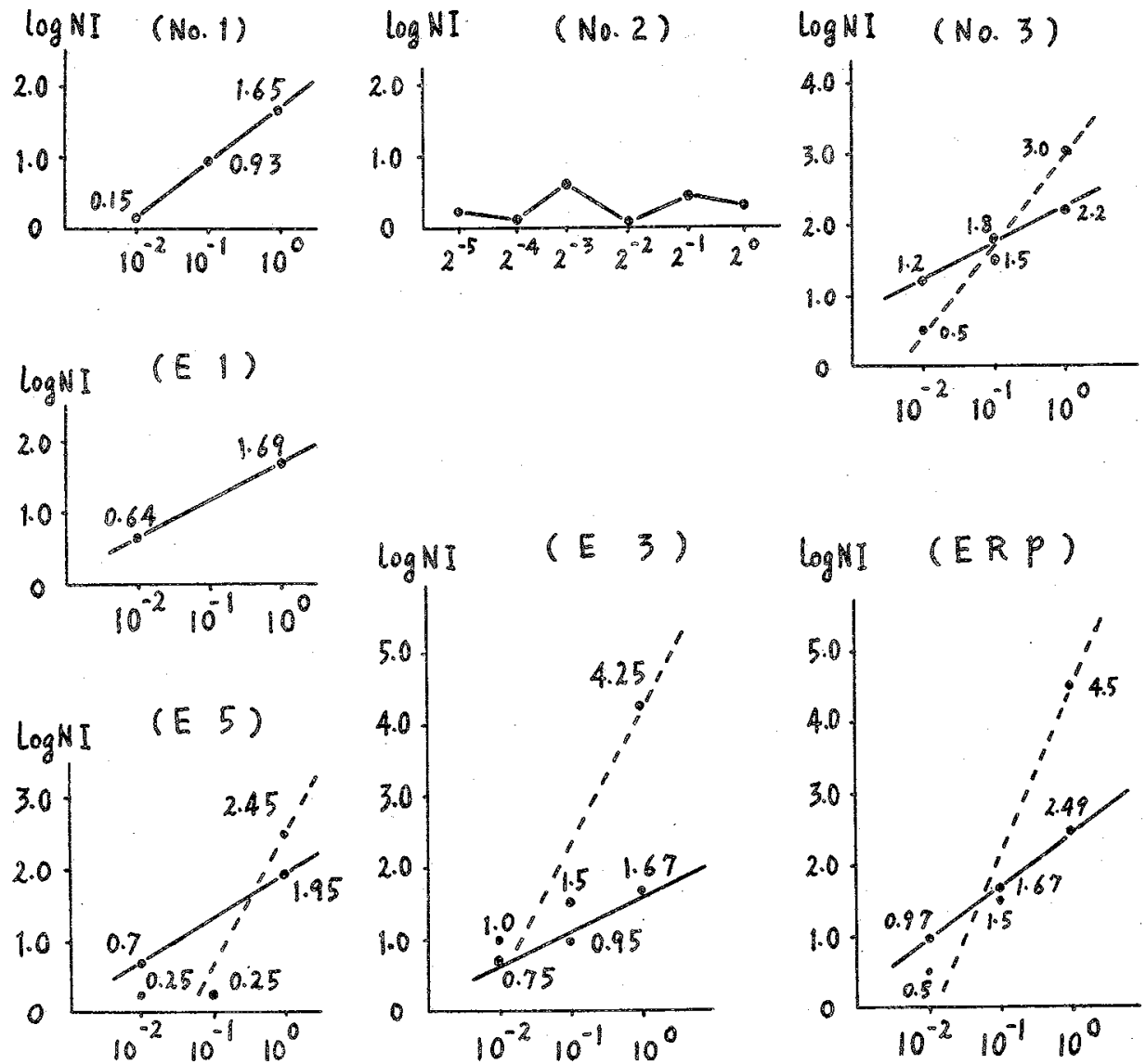

Notes 1) Horizontal axis: Serum concentration

Vertical axis: Neutralizing capacity

2) - - - : Neutralization line against vaccinia virus

- Neutralization line against ectromelia virus

3) Immunization

No. 1, No. 2, No. 3: See notes in Table 1.

E 1: Injected with $5 \mathrm{ml}$ of $10 \%$ emulsion of the ectromelia mouse liver five times intraperitoneally at weekly intervals, and bled 9 days after the last injection.

$\mathrm{E} \mathrm{3,} \mathrm{E} \mathrm{5:} \mathrm{Injected} \mathrm{in} \mathrm{the} \mathrm{same} \mathrm{manner} \mathrm{as} \mathrm{in} \mathrm{E} \mathrm{1,} \mathrm{and} \mathrm{bled} 15$ days after the last injection.

ERP: Injected with $5 \mathrm{ml}$ of $10 \%$ emulsion of the ectromelia mouse liver four times intraperitoneally at intervals of five days. Bleeding was made 10 days after the last injection and pooled serum was used.

両中和反応にあずかる諸因子の中に，異質のものが含ま れているのではなかるうかと教えられたので，その点に ついて検討した.

上述の二つの中和曲線の傾斜の差異が現われる原因と して先ず考えられることは，中和反応の場が E-ウとV-ウ とで異つているという点である。そこで，試みに抗V.ウ サギ血清を用いて E-ウおよびVーウに対する中和曲線の 関係をしらべたところ，眓2のよらな成績がえられた。
抗Vウサギ血清の作り方：10 $0^{-1} \sim 10^{-7}$ の各生ウイル 又稀釈液 $0.1 \mathrm{ml}$ を 4 個所ずつ背部皮内に接種し，2 週後にウイルス原液(ウサギ皮内 $0.1 \mathrm{ml}$ 接種で $10^{-6}$ の発痘力価を有する） $1 \mathrm{ml}$ を耳静脈内に接種した後 1 週目に採血した。

図に文られるよらに，抗Vウサギ血清においては，抗 Eウサギ血清の場合とは異り，対 E-ウ中和曲線の傾斜 は急で，対 V-ウ中和迪線の傾斜と殆んど差がみられな 
からた.

すな⿰ち，抗 血清対 V-ウの中和曲線の傾斜は急で常に同じような值

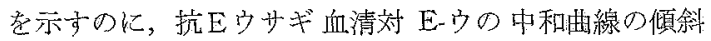
は师るや为である場合が多く，しかも時に法抗Vウサギ 血清の場合のように，これが急になつて対Vーウの場合 と差のない程度になること肪るる。そこで、このような 現象の原因を検討するため，以下述心るよらな実験をお こなつた。

Fig 2 Neuralization line of anti-vaccinial rabbit serum against ectromelia and vaccinia viruses
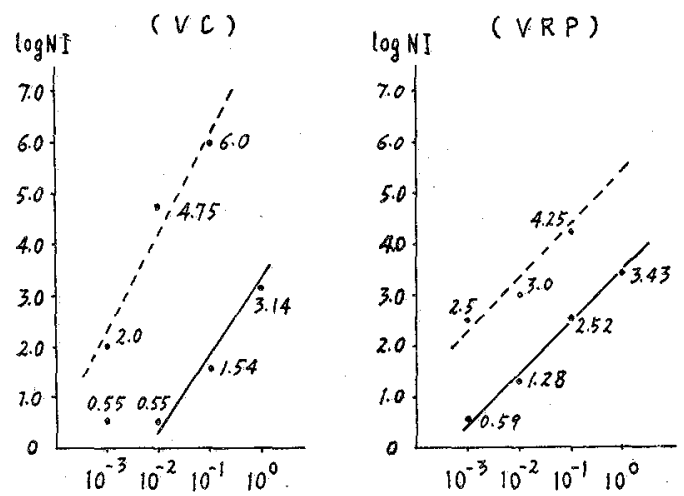

Notes

1) Horizontal axis : Serum concentration Vertical axis: Neutralizing capacity

2) - - : Neutralization line against vaccinia virus

_- : Neutralization line against ectromelia virus

3) Immunization

Two weeks after the intracutaneous injection of vaccinia virus, injected intravenously with $1 \mathrm{ml}$ of vaccinia seed virus suspension, and bled one week after the second injection.

(VC) : Serum of an immunized rabbit

(VRP) : Pooled serum of ten immunized rabbits

実験 IV 抗Eマウス血清と E-少およびV-ウとの中 和曲線

抗Eウサギ血清対 E-ウの中和曲線の傾斜は，一般に ゆるやかなことを䒠験 II で述べた，そしてこのような現 象注必ずしも E-ウの中和反応の場によるものではない で亦ろらといらことが，実験而の成績から考察された。

そこで，このような現象の原因として煞疫に使用する 動物の敇の問題をとり上げて検討を試みるため，抗 Eマ

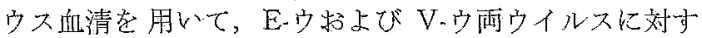
る中和曲線を求めてみたところ，図 3 のような成績功え 它被不。
抗Eマウス血清の作引方：10\%不活化 E-ウ液（作 り方は第 1 報を参照) $0.25 \mathrm{ml}$ を 1 週閒隔で 3 回腹腔 内に注射し， 1 週後 $10^{-2}$ 生 $\mathrm{E}$-少澕 $0.25 \mathrm{ml}$ 学腹腔内 に注射した。最終注射後 10 日目に生残又ウス加ら採 血し血清を集めた。

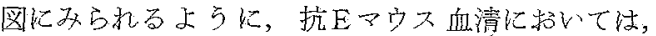
V-ウに対する中和曲線の傾斜は急であるのに効し，E-ウ に対する中和曲線の傾斜はゆるやかであり，抗Eウサギ 血清の場合亡同様な成績がえられた。

抗ウサギ血清と抗 $\mathrm{E} マ$ マ血清との間で，E-ウ，V-ウ の耐中和曲線に関して同様な現像がみられることから，

Fig. 3 Neutralization line of anti-ectromelial mouse serum against ectromelia and vaccinia viruses
(EM 1)

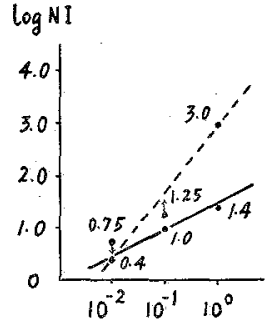

$(E M 2)$

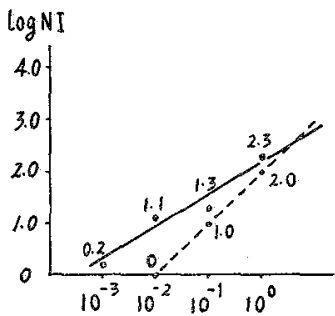

Notes

1) Horizontal axis : Serum concentration Vertical axis: Neutralizing capacity

2) -.. : Neutralization line against vaccinia virus

_- : Neutralization line against ectromelia virus

3) Immunization

Injected with $0.25 \mathrm{ml}$ of $10 \% \mathrm{UV}$ inactivated ectromelia virus suspension three times intraperitoneally at weekly intervals, and injected with $0.25 \mathrm{ml}$ of $1 \%$ living virus suspension intraperitoneally one week after the third injection. Bleeding was made 10 days after the last injection and pooled serum was used.

抗Eウサギ血清対 E-ウの中和曲線の傾斜がほるやかな ことの原因しして，ウサ甫対 E-ウといら特殊な関係走 考光ることは無理のよらに思われる。

な执，抗Eマウス血清中には，抗Eウサギ血清の場合 に考えられる正常マウス肝組織に対寸る抗体法考え難い ので，もし抗Eウサギ血清対 E-ウの中和曲線の傾斜が ゆるやかであるという現象を㟟き起すのに，正常マ少ス 肝組織に対する抗体が何等かの役割を果しているのなら ば，抗Eマウス卹清に扔いては上述のごとき結果がえら

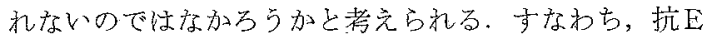
ウサギ血清対 E-ウの中和曲線の㑯斜が特に沛るやかな 
のは，その血清中に含まれる正常マウス肝組織に対する 抗体のためではなかららと思和机る。

実験 $V$ 抗 $V$ マウス血清と E-ウおよび $V$-ウとの中 和曲線

前述の諸実験の成續から，抗Eウサギ血清対 E-ウの 中和曲線の傾斜が特にゆるやかである原因の一つとし て, 免疫原としての E-ウの特殊性が考光られた. そこ で，免疫原として E-ウを用いることが，このような現 象を惹き起す原因であるかとらかを検討するため，抗V マウス血清を用いて E-ウ，V-两ウイルスに対する中 和曲線を求め，雨曲線の関係をしらべたところ，図 4 の よらな成績がえられた。

抗Vマウス血清の作り方：生 V-ウ液（ウサギ皮内 $0.1 \mathrm{ml}$ 接種で $10^{-6}$ の発痘力価を有古るもの）を用い て次のよ らに腹腔内に注射した. $10^{-1}$ 稀釈液 $0.5 \mathrm{ml}$ 注射後約 1 週閒隔で 3 回ウイルス原液を注射し, 最終 注射後 1 週目に採血し血清を集めた.

Fig. 4 Neutralization line of anti-vaccinial mouse serum against ectromelia and vaccinia viruses

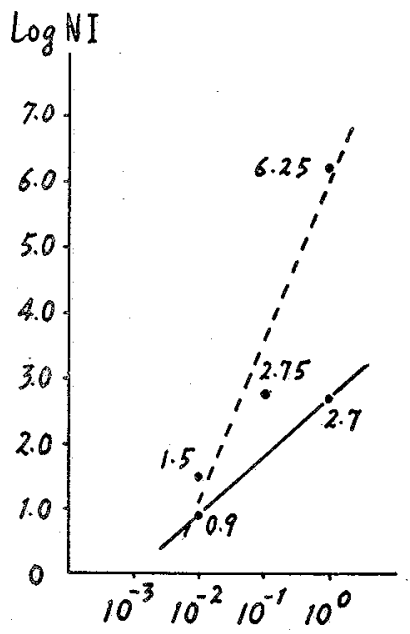

Notes

1) Horizontal axis: Serum concentration Vertical axis: Neutralizing capacity

2) - - : Neutralization line against vaccinia virus

_. Neutralization line against ectromelia virus

3) Immunization

Twenty mice were injected with $0.5 \mathrm{ml}$ of $10 \%$ diluted vaccinia virus suspension intraperitoneally, thereafter injected with $0.25 \mathrm{ml}$ of vaccinia seed virus suspension three times intraperitoneally at intervals of 7 days. Bleeding was made 7 days after the last injection and pooled serum was used.
図にみられるように，抗Vマウス血清に拉いては，対 V-ウ中和曲線の傾斜は急であるのに対し，対 E-ウ中和 曲線の傾斜はゆるやかであり，抗上ウサギ血清および抗 Eマウス血清におけると同様な成績がえられた。

すなわら，E一ウに対する中和曲線の傾斜が特にゆるや かであるといら現象は，V-ウを免疫原とした場合にもみ られたわけで，このよらな現象の文られる原因表，免疫 原としての E-ウそのものに蛝することはできないと考 えられる。

さて，以上述べてきたように，V-ウに対する中和曲線 の傾斜が急であるのに対して，E-ウに対する中和曲線の 傾斜がゆるやかなことは，抗Eウサギ血清の場合の夕で はなくて，抗Vウサギ血清以外の抗血清の場合にはいず れもみられる現象であつて，E-ウに対する中和曲線の傾 斜が特にゆるやかであるといら現象の原因として考えら れた中和反応の場の問題，あるいは E-ウとの関連にお いて考えた偊疫動物の種特異性, あるいは抗原構造上か ら考えた免疫原としての E-ウの特異性などは, す心゙ 否定されたわけである。したがつて，その原因は中和試 験をおこなう時時の抗体側にあるのではなかるらかと考 えるよらになつた。

実験 VI 中和曲線の傾斜に去よぼす免疫方法の影響 免疫の時期や免疫の方法によつて質的に異つた抗体が 見出されることが指摘されている。これらの報告によれ ば，この質的差異が中和曲線の傾斜の差として現われる 可能性が考元られる。私共は，免疫過程にお活る抗血清 の性状の変化をみるために，中和曲線の傾斜に捛よぼす 免疫方法の影響について 2,3 実験を試みた.

これまで述べた抗Vウサギ血清は，生 V-ウを皮内接 種または乱切接種した後, 静脈内に追加免疫をなこなつ たもので，E-ウとの中和曲線図５で点線の示すような むのであることは既に述心た。 そこで，試みにV・ウに よる乱切接種の夕学扢こなつた後，2週目の血清につい て，E-ウに対する中和曲線を求めたところ，実線で示す ようなゆるやかな傾斜をすつた中和曲線がえられた。す なわち，同一抗原材料を用いてもその免疫方法や時期に よつて，中和曲線の傾斜を異にする血清がえられること がわかつた。

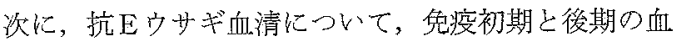
清を用意しそその中和曲線の傾斜を比べてみた、今 感染マウス肝 $10 \%$ 乳剂を 1 週間隔で 2 回注射後 1 週目の 血清を初期血清， 1 週間隔で 5 回注射後 1 週目の血清を 後期血清と仮りに名付ける。

先ず E-ウを用いて中和試験をおこなつたところ，図 6 に示すよ5に，後期血清の中和曲線としては実線で示 
Fig. 5 Influence of method of immunization on slope of neutralization line. (No. 1)

Neutralization line of anti-vaccinial rabbit serum ( 2 weeks after the scarification) against ectromelia virus

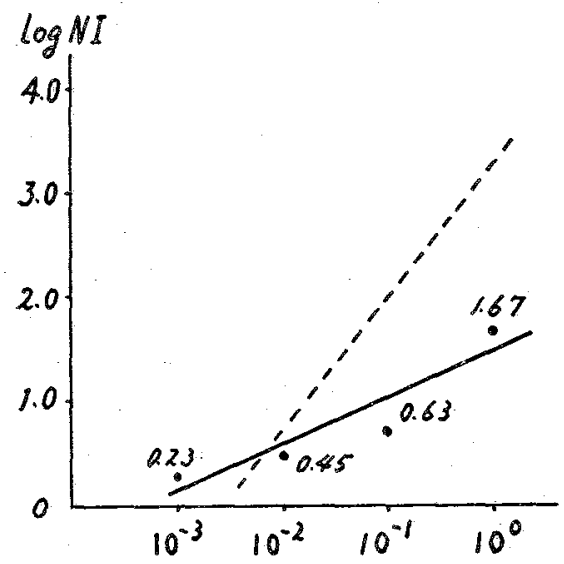

Notes

1) Horizontal axis: Serum concentration Vertical axis: Neutralizing capacity

2) — : Bled 2 weeks after the scarification.

- - : This case was boosted intravenously with

$1 \mathrm{ml}$ of vaccinia seed virus suspension

2 weeks after the scarification.

Fig. 6 Influence of method of immunization on slope of neutralization line. (No. 2)

Comparison of neutralization lines of antiectromelial sera of rabbits immunized

2 and 5 times against ectromelial virus infection in mice

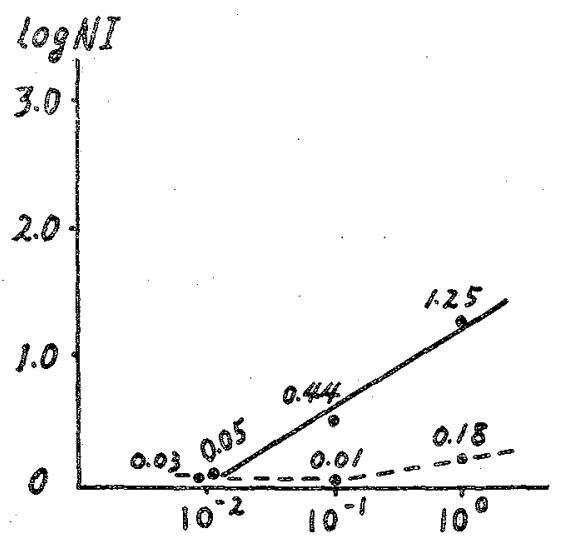

Notes

1) Horizontal axis: Serum concentration Vertical axis: Neutralizing capacity

2) - - : Earlier stage of immunization - : Later stage of immunization
Fig. 7 Influence of method of immunization on slope of neutralization line. (No. 3)

Comparison of neutralization lines of antiectromelial sera of rabbits immunized

2 and 5 times against vaccinial virus infection in rabbits

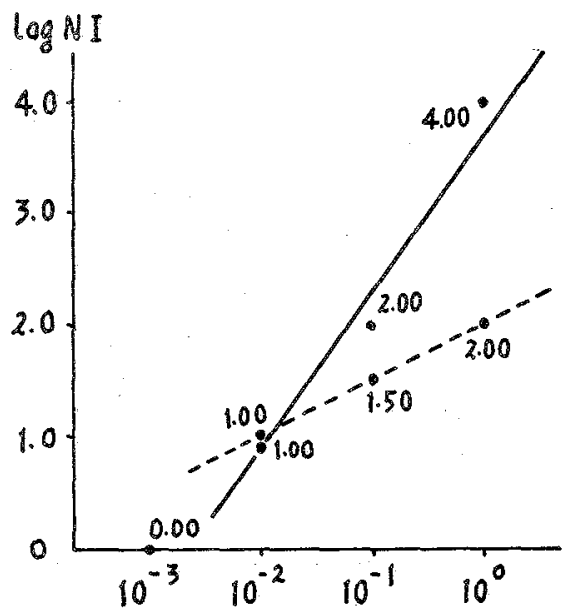

Notes

1) Horizontal axis: Serum concentration Vertical axis: Neutralizing capacity

2) -- - : Earlier stage of immunization - - Later stage of immunization

すようなこれまで述べてきたと同稼な傾斜を有する曲線 がえられたが，初期血清には中和能住琹められなかつた ので両血清の中和曲線の比較はできなかつた。

さて，E一に対して中和能が認められない抗Eウサギ 血清でもV-ウに対しては中和能が認められることを， かつて経験しているので，E一の代りにV-ウを用いて 上記雨血清の申和曲線を求めてみたところ，図7のよう な成績がえられた。点線注初期血清, 実線任後期血清を 用いた場合の中和曲線である。図に示したように，注射 回数の増加と其に中和能の上昇が多られるが，それと同 時に中和曲線の傾斜の変化が办られている。

以上の成續加ら；同一材斜索用いても免疫の方法要当 いは免疫の時期によつて中和曲線の傾斜を異にする抗血 清汃えられることがわかつた。

突験 VII E-ウ免疫ウサギのV-ウ発痘阻止能につマ $\tau$

E-ウ危疫ウ步ギの V-ウ発痘阻止能に関して，第 1 報 とやや異つた成績汃今回えられたことを案験Iの項で述 ふだこの点について若干検討を試みたので，ての結果 について次に述心゙る. 
䒠験 VII-1 E-ウ免疫ウサギ，V-ウ免疫ウサギおよび 健常ウサギのV-ウ接種後に抬ける発痘経過

先ず次のような 3 群のウサギを用意した。

E免疫群：E-ウ感染マウス肝 $10 \%$ 乳剂を $5 \mathrm{ml}$ すっ 1 週間隔で 5 回腹腔内に 注射し，最終注射後 16 日目に V-ウの攻撃をおこなつた、V-ウ攻撃接種㨁前の血清中和 能は, 図1中(E3), (E5) に示してある.

V免疫群：抗Vウサギ血清（100 倍稀釈液で約 2.5 の

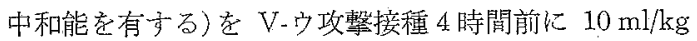
静脈内に注射したもので, 攻撃接種直前における血清は 原液で 6.0 以上の中和能を示した。

対照群：健常無処置ウサギでV-方攻擊接種前の血清 中和能は 0 であつた。

以上のような各群 2 頭のウサギに対して，同時にその 背部皮内に V-ウを接種して力洒試験をおこなつた.ウイ ルスの各稀勫液につマて 4 個所すつ接種し，毎日その発 痘の程度を観察し, Reed \& Muenchの方法により ID 高算出した。 その結果, 因8のような成績がえられた。

Fig. 8 Inhibition of vaccinia dermal infection in rabbits immunized with ectromelia virus

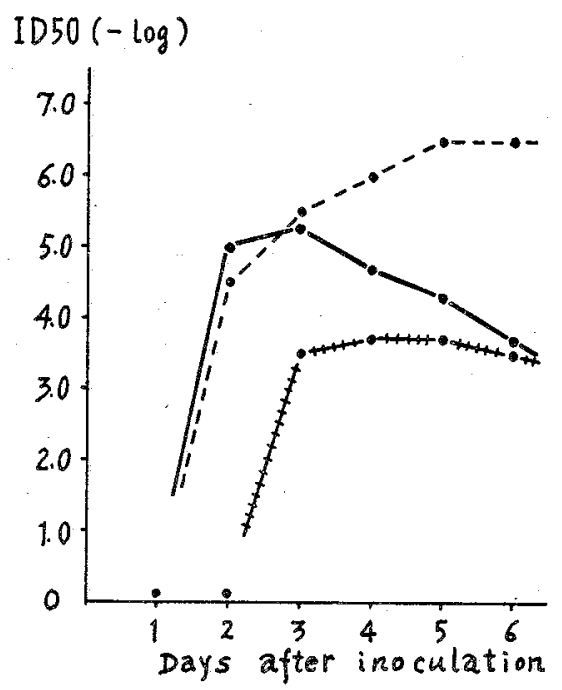

Notes

- - : Normal rabbits

HWH : Passively immunized rabbits with anti-vaccinial serum

Actively immunized rabbits with ectromelia virus

すなわち，煡常ウサギにおいては，従来の報告および 私共の経験しているように，その発痘の程度はりイルス 接種後日経ると其に増大し，発痘力価は５日目垻最高 值を示し，以後そのまま持続する，それに対して E-ウ 免疫ウサギに煞いては, ウイルス接種後 3 日目頃最高值
を示し，その後は次第に減退する傾向肪みられた。つま り，発痘の経過が両者の場合で異なることを見出した。 このことは，同じく発痘といつても両者の間に拉こなか れている機作には巽る点があるのかすしれないと思わせ るものであつて, それらの発痘を比較して発痘阻止の問 題を論ずる場合には留意されなければならないことであ ると思われる、V-ウ被働性免疫りサギでは，健常ウサギ に比べ発痘力価がかなり下まわつているが，その経過は 健常ウサギと同じような傾向であつた。

帘験 VII-2 E-ウ免疫ウサギに䑙当 V-ウ増殖曲線

$\mathrm{E}$-ウ免疫ヴサギの $\mathrm{V}$-ウに対する増殖阻止能を直接検 討するため，次に E-少先疫ウサギの皮内にV-ウを接種 し，接種後日を追つて局所のウイルス量をしらべてみ t.

すなわら，E一ウ免疫ウサギおよび健常無処置りサギ各 3 頭ずつを用意し， $1000 \mathrm{ID}_{50}, 100 \mathrm{ID}_{50}, 10 \mathrm{ID}_{50}$ の V-ウ 稀釈液を 1 稀勫につき数個所ずつ各ウサギの背部皮内に 接種した。接種後日を追つて局所皮膚索径約 $2 \mathrm{~cm}$ の大 きさに 2 個ずつ切り取り，乳剂として凍結融解を 3 回お こない，3000 rpm 15 分閒遠心泌涉した上清について， 新しいウサギの背部皮内接種で感染価をしらべた。

その結果は図 9 にみられるよらに，E-方免疫少少だに おいては，ウイルス力価が健常ウサギに比べて終始下ま わつていた，更に興味ある点は，E一ウ免疫ウサギと健常 ウサギとではウイルス堌殖曲線の型の上でも異つてお り，前者で性 4 日目钼から急にウイルス量の減少がみら れたことである。

また，両ウサギに和ける発痘の経過について，発赤の 大きさを目やすとして比べてみと，前の実験結果と同 様に両者の間で発痘経過に差異がみられた。すなわら， 接種後 4.日頃までは，E-ウ免疫ウサギにおける発痘の程

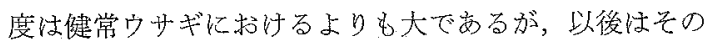
関係が逆になるＥ一方免疫ウサギではウイルス増殖の实 では健常ウサギより終始下まわつているにも拘らず，こ のような現象が多らるのは，接種後4 日頃までのE-ウ 免疫当ギにみられる発赤硬結は，ウイルスの増殖によ るほかに，更に他の因子加加わつてみられるものと考光 られる。

\section{考察}

1. 抗Eウサギ血清の E-ウに対する中和能について 第1報でも述べたように，従来 E-ウでウサギを免疫 した場合における E-ウに対する中和抗体の産生に関し ては；一致した結論はえられていないようであるが，私 共は，ウサギでは E-ウ亿対する中和抗体は極めて産生 し難いと考えてきた，今回の実験に就ても，第】報で 
Fig. 9 Multiplication of vaccinia virus in rabbits immunized with ectromelia virus

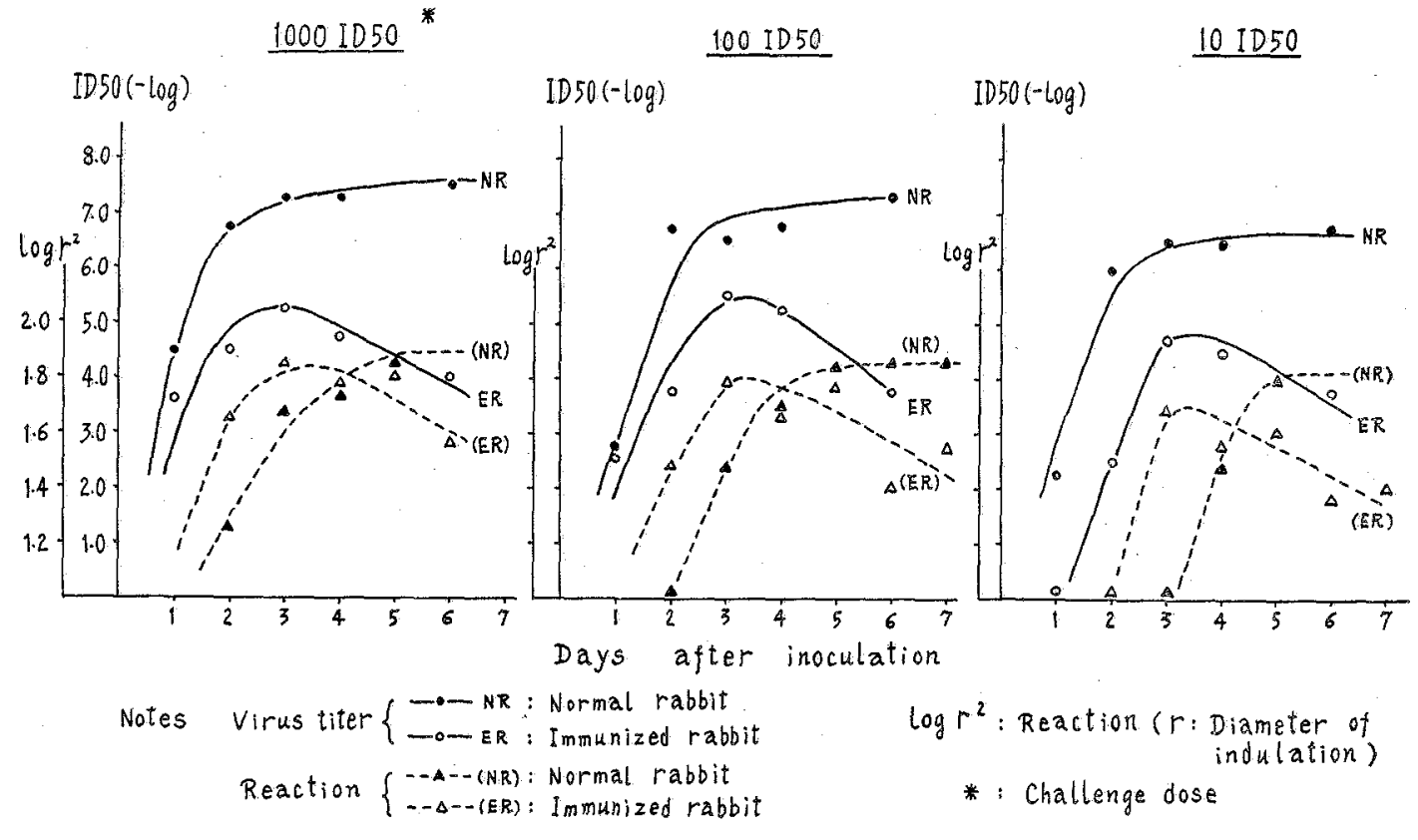

述べたと同樣，高い中和能（血清濃度を一定としたウイ ルス稀瀵法により算出したもの) 在むつ抗 Eウサギ血清 をらることはすくなか加った。

ここに注意さるぶきことは，抗Eウサギ血清の示す E-ウに対する中和曲線の傾斜が極めてゆるやかで，一般 にその值は約 0.5 前後を示したことである. 私共の今回 の実験範囲内では，E-ウに対して高い中和能を有する抗 Eマウス血清をらることは，必ずしも容易でなかつたこ とをあわせ考えるとき，中和能吕低く，要るい保誤差範

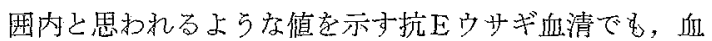
清濃度と中和能との間の相関を示す一定の中和曲線がえ られる場合には，中和抗体は産生されているのである と判断するのが妥当と考える。すなわち，中和曲線から みると，抗Eウサギ血清住 E-ウに対する中和抗体がな いのではなく，相当濃厚にもつていながら中和能が低い ために譛識し難いのであるちと考えられる。仮りに，少 量のウイルスを用いて，ウイルス量を一定とした血清稀 橎法により中和試験を和こな度ば，抗Eウサギ血清のご とく中和曲線の傾斜功束るやかな抗血清につけては，か なり高い中和抗体価(いわ沛る $\mathrm{ED}_{50}$ ) が求められるわけ

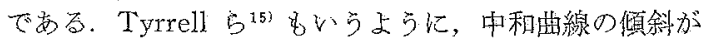
わからないときには，ウイルス量を一定とした血清稀釈 法の採用を孝慮する必要怔あるう. 結局, 中和抗体の量 (濃度)をはかるためには，血清稀釈法が妥当であつて， 中和能はさしろ抗体の質をあらわすものではなかるらか
と考える。

ところで，E-ウ免疫ウ将ギにおける中和抗体産生の問 題をとりあつから場合に，先ず注意せ䄈ばならないの は，V-ウによる使用ウサギの栃染の問題であるのはいう 安でもない。この点は, 本実験を通じて私共功終始留意 したところで，実験ごとに厳重な消毒と動物の飼育管理 を捻こない，使用ウサギは実験前にすべて血清反応によ

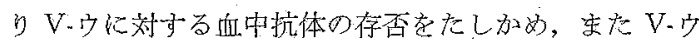
污染を検出するための対照群を常に同じ環境に括いて観 察した。なお，E-ウに対する中和能がみられる抗Eウサ ギ血清成えられたことは，このV、ウ污染に最も留意す べき点であるが，この E-ウ免疫ウサギが，V-ウの污染 字らけていた上に E-少の booster effect があらわれた ためではなかららかといら心配も，抗区ウサギ血清が E-ウに対して示す中和曲線の傾斜によつて，あ方程度否 定できるのではなかららか。立た，V、ウ励染ウサギが免 疫に使用されたとしたら，図6の塞験に打ける初期血清 に拉いて既に中和能がみられてもよい筈であるう。この こと加らを E-方注射による booster effectによつて抗 Eウサギ血清が E-ウに対して中和能を示したとは考え 難い、更に，図6および図 7 に示した成績は，E-少の免 疫注射の回数が増すにしたがつて申和能の上昇があつた ことを示唆して晾り，免疫期間中にV-少の感染吕女つ たとは考え難い，以上のことから，実験中に扔けるV-ウ の污染は一応除外することができると考えられる。 


\section{2. 中和曲線の傾斜につマて}

実験の初期において，抗Eウサギ血清と E-ウとの中 和曲線の傾斜性極めてゆるやかであるのに対し，Vーウと の中和曲線の傾斜は急であつて両中和曲線が平行しない ことを見出した，そしてこのことは抗 Eウサギ血清の一 特性ではなかるうかと考えた。しかし実験の進展にした がつて，抗Vウサギ血清以外の抗血清，すなわら抗 $\mathrm{E} マ$ ウス血清および抗Vマウス血清に稀いても抗Eウサギ血 清と同稼な現象がみられることがわかりり，更に，免疫の 方法によつては，E少に対する中和曲線の傾斜の上で抗 Eウサギ血清と同しような態度を示す抗Vウサギ血清が えられることもわかつた，そして，E市に対する中和曲 線の傾斜が一般に涑るやかでめるといら現象の原因では ないかと考えられた E-ウの中和反応の場，あるいはウ サギ対 E-ウといら特異な関係，あるいは E-ウの抗原構 造上の特異性などは一応否定された。

更に実験Vの成績によつて，同一材料を用いて免疫し た場合にも兔疫方法あるい浪疫時期によつて中和曲線 の傾斜を異にする抗血清功えられることが明らかとなつ た，乙して私共の中和試験に用いた系においては，免疫 の程度が高くなるにしたがつて中和曲線の傾斜が大さく なるのではないかと思われた。

さて，中和曲線を求める実験全体を通じて，V-ウに対 する中和曲線の傾斜が急である抗血清索うることは比較 的容易で，私共の用いた抗血清は殆んどす心゙て $1.0 \sim 2.0$ の傾斜学示したが，E一ウに対子る中和曲線は，極好て強

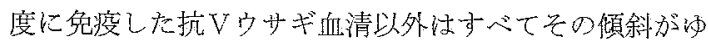
るやかで約 0.5 前後の暄を示した. しかし，ここに用い た抗玉ウサギ血清は大量頻回注射して得られた血清であ り，Ginsberg "3) が考察しているウイルス側の因子をむ 考慮して，この傾畬と免疫方法の関係については今後解 明されるべさ点が残されていると考える。

一方, Raffel \& Terry $^{13)}$, Kekwick \& Record ${ }^{11}$, Burnet \& Fenner"), Jerne ${ }^{9 \prime}$, Jerne \& Avegno ${ }^{102}$, Ward et al. ${ }^{16)}$, Humphrey \& Porter $^{81}$, Sabin ${ }^{14)}$, Brunner \& Ward $^{21}$ ら法免疫の時期あるい住疫方法によつて質的 に異つた抗体吕見出されることを指摘しており，また， Horsfall \& Lennette ${ }^{6)}$, Ward et $\mathrm{al}^{16)}$., Jerne \& Avegno $^{101}, S_{a b i n}^{14)}$, Brunner \& Ward $^{21}$ らにより, 主とし てウイルスと抗体の結合解離の面加ら質的に異つた中和 抗体の存在が論ぜられているのは興味あることと考え る.さて，本報告で述べたような中和曲線の傾斜の差と いうものは，生物学的にはどのような意昧をむつている のであろらか。ウイルスを抗体結合物の安定性（稀䆏現

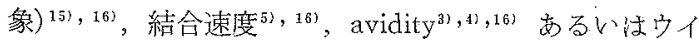

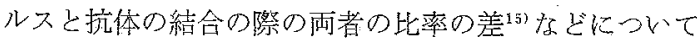

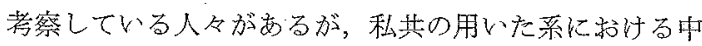
和反応にこれらの事柄がどのようにあてはまるかは，今 後の実験の進展に俟ちたいと思う。

3. E-ウ免疫ウサギの V-発痘阻止能について

E-ウ冕疫ウサギに拉いては，共通抗原を有するV-ウ 皮内接種に際して局所アレルギー反応が起ることが考光 られる。しかも杂れが，ツ心゙ルクリン型のむのであるな らぼ，E-ウ筧疫ウサギにV-ウを接種した後比較的短時 日である 3〜4 日後に拉いて恃，V-ウ増殖による発赤， 腫脹，硬結とアレルギー反応によるそれとが重なりあっ て、V-ウによる発痘の有無の判定をあやまらしめる恐机

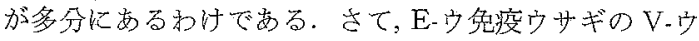
発痘阻杫能に関して，第 1 報とやや異つた成績が党られ たが，これは前回に掠いて蛙疫後のアレルギ一反応が 比較的弱く，今回はそ㧈加比較的強加つたのではないか とも考えられる。いずれにしても，E一ウ免疫という前処 置ウサギを用いた場合と，健常ウサギを用いた場合と同 一判定基準によつて V-少の力価試験をおこなつたとこ るに，そのような成績がえられた原因があつたのではな かるら加と考它られる。

次に，E-ウ免疫ウ壮にV-ウを皮内接種した場合に， 健常ウサギとは異つて，接種後 4〜5 日頃加ら局所のウ イ゙ルス量の低下がみられることであるが，これ性健常ウ サギとは異つて E-ウ免疫りサギの場合には，V-ウ接種 後比較的短時日の間に局所の中和抗体が産生されるので はないかと考完られる点があるが，小島到らのいら発痘 抑制因子の性状もあわせて考慮す心゙きであるら。

\section{総括}

第 1 報に引き続き，ウサギを用いて E-ウの免疫血清 学的研究学拈こなつた。

先ず，E-ウ免疫ウサギにおける中和抗体（E-ウおよび V-ウに対する）産生の問題をとり上げ，実験例数を増す と共に，中和曲線によるそれの解明を試みた。更に， E一ウ执よびV-ウに対する抗Eウサギ血清の中和曲線に 関してやや特異な性状が認められたので，抗Vウ少ギ血 清, 抗Eマウス血清执よび抗Vマウス血清とついてあわ せて検討すると共に，中和曲線の傾斜に执よぼす免疫方 法の影響についても若干検討した. その結果, 中和曲線. の傾斜に関して $2 ， 3$ の知見がえられた。

また，E-ウ免疫ウサギの V-ウ登痘阻止能について検討 するため，V-ウ免疫ウサギおよび健常ウサギと対比しな がら，Vーウ接種後における発痘経過立びにV・ウの堌殖 過程を推察した結果，やや與味ある知見がえられた。

以下笑験成績について述へる。

1.E-ウでウサギを強度に免疫した場合にも，E-ウに 
対子る中和能を明らかに諗める血清は得難いことは事実 であるが，抗Eウサ戈血清とE-ウとの中和粗線の特性

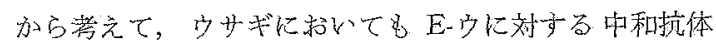
痖生しているのではなからかと教えられた。

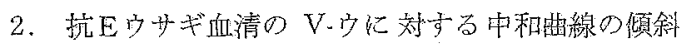
注急であるのに対して，E一济を対する中和曲線の傾斜は 概してゆるやかで，雨响線は平行しないすのと思われ た.このことは抗E-ウサギ血清とE-ウおよびV-ウとの 中稩能怔平行しないといら成績と符合するものであり， 更に雨ウイルスに対する中和能の高低を比較諭ずること の不合理性を示晙するものと思われた。

3. 抗Eウサギ血清の E一ウに刘子る中和相線の頙斜 が特にゆるやかなことは，E一の中和反忘の場，あるい

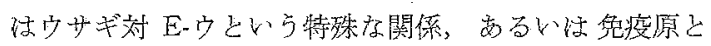
しての E-ウの特異性などが要因となつてあらわれるむ のといらよりは，恐らくその時時の抗血清側にその要因 が含まれているので待なかららかと考察された。

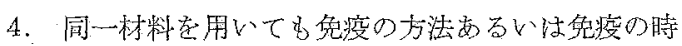
期によつて中和曲線の傾斜定翼にする抗血清加えられる ことがわかつた。

5. E-ウ免疫ウサギにVーウを皮内接種した場合には， 健常りサギの場合とはをの発痘の経過およびV-ウの增 殖曲線に差翼がみられ，このこと梳痘の機作汃雨者 で異ることを意味するのではないかと思われる。つま

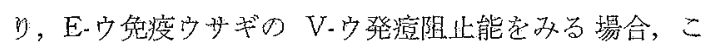
の点に充分留意しなければならないと考える.

終り下臨み，御指導御校閲支賜つた予研黑川正身博士

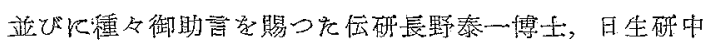

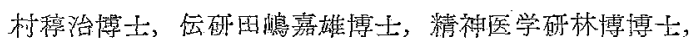
故妿東滑博土飞謝意を表します。亦を本研究遂行にあた わ，御拹力党得を研究空の諸氏に感謝します。

\section{Summary}

Successively from the first report, the immunological and serological investigations on the ectromelia virus was carried out using rabbits.

In the first place, the problem of development of neutralizing antibody (VN antibody) against ectromelia and vaccinia viruses in rabbits immunized with the ectromelia virus, was taken up. Its elucidation was attempted by the increase in number of experiments and by using the neutralization line of immune serum. Concerning the neutralization line of anti-ectromelial rabbit serum against ectro. melia and vaccinia viruses, the singular property was recognized.

And so the investigations was done about each neutralization line of the anti-vaccinial rabbit serum, the anti-ectromelial mouse serum and the antivaccinial mouse serum, like in the anti-ectromelial rabbit serum.

The influence of method of immunization on the slope of neutralization line was investigated.

In order to see the inhibition of vaccinia dermal infection in rabbits immunized with ectromelia virus, the courses of pox-pustulation and virus multiplication after the inoculation of vaccinia virus were observed in rabbits of normal and immunized with vaccinia and ectromelia virus.

The results are summarized as follows.

1. Even in rabbits immunized repeatedly with the ectromelia virus in large quantities, the serum which the neutralizing capacity against ectromelia virus can be recognized clearly, was not easily obtainable. However, considering the property of neutralization line, the VN antibody could be produced in rabbits.

2. The slope of neutralization line of antiectromelial rabbit serum against vaccinia virus was steep, on the other hand, that against ectromelia virus was flat on the whole, thus two neutralization line were not parallel. This phenomenon is consistent with the fact that the neutralizing capacities of antiectromelial rabbit serum against ectromelia and vaccinia viruses were not parallel. The mechanism of the mode of neutralization reaction against both viruses might not be analogous.

3. The phenomenon that the slope of neutralization line of anti-ectromelial rabbit serum against ectromelia virus was flat, might be caused by the property of the anti-serum itself, rather than by the system of neutralization test, or the particular relation of rabbit to ectromelia virus or the singularity of ectromelia virus as immunogen.

4. The different slopes of neutralization line were obtained due to varying methods of immunization or varying periods of immunization, even though using the identical material.

5. When the rabbit immunized with ectromelia virus was intracutaneously inoculated with the vaccinia virus, the course of pustulation and the growth curve of vaccinia virus was different from that in the normal rabbit. It was suggested by this fact that the mechanism of vaccinia dermal infection was different in these animals. The attention should be directed on this a point, when the inhibition test of vaccinia dermal infection in rabbits immunized with ectromelia virus was attempted.

\section{文献}

1) Burnet, F. M. and Fenner, F. (1949). The production of antibodies, 2 nd. Ed., Mcmillan \& Co. Ltd, London - 2) Brunner, K. T. and Ward, R. (1959). J. Imm., 83, 405-410. - 3) Ginsberg, H. 
S. (1956). J. Imm., 77, 271-278. - 4) Ginsberg, H. S. (1957). Ann. New York Acad. Sci., 67,383391. - 5) Horsfall, F. L. (1939). J. Exp. Med., 70, 209-222. - 6) Horsfall, F. L. and Lennette, E. H. (1941). J. Exp. Med., 73, 327-333. -7) 堀 江喜一，㭙上忠亚 (1954). 少ルス，4，115-122。 8) Humphrey, I. H. and Porter, R. R. (1956). Biochem. J., 62, 93-98.. -9) Jerne, N. K. (1951). Acta. path. microbiol. Scandinav, Suppl., 87, 3-183. -10) Jerne, N. K. and Avegno, P. (1956). J. Imm.,
76, 200-208. -11) Kelwick, R. A. and Record, B. R. (1941). Brit. J. Exp. Path., 22, 29-43. - 12) 小嚳保彥(1959)，ウイルス, 9, 347-351. -13) Raffel, S. and Terry, M, C. (1940). 'J. Imm., 39, 349-360. -14) Sabin, A. B. (1956). J. A. M. A., 162, 1589 1596. - 15) Tyrrell, D. A. J. and Horsfall, F. L. (1953) J. Exp. Med., 97, 845-861. -16) Ward, R., Chang, C. and Rader, D. (1955). Proc. Soc. Exp. Biol. \& Med., 90, 162-165.

\title{
第 2 回バクテリオファージ講習会に ついてのお知らせ
}

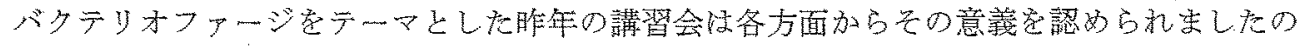
で今年も引続いて金沢大学で開催することになりました。

この請習会は活登に進歩しつつある科学研究の領域の中で視野の広い研究者を養成し，生命 現触に関子る基礎的な研究分野の発展を目的と古るものです，内容はファージの基礎知織と技 術の臽得を主とし実垍及び講義定行います。

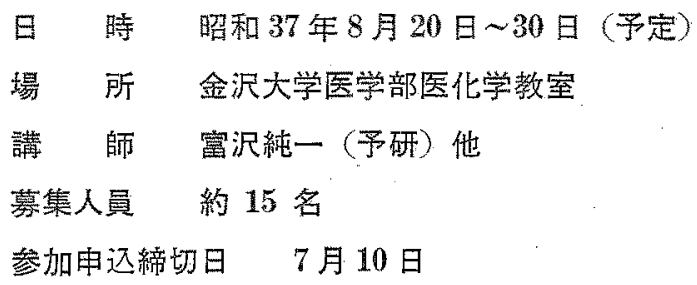

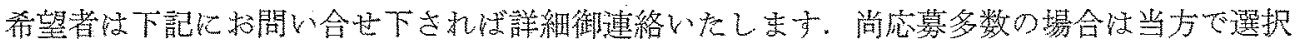
することがありますから予めご承知打き下さい。

\author{
連絡先 金沢市土取場永町 15 \\ 金沢大学医学部医化学教公内
}

第 2 回フアージ講習会準備係 